\title{
ピロ燐酸カルシウム結晶（CPPD）沈着症により 手指伸筋腱断裂を来たしたと思われる1例
}

今村 仁

\section{目 的}

今回我々は, 自然経過の中で手指伸筋腱皮下 断裂を来たし, 術後病理組織検査にて断裂部位 周囲にピロ燐酸カルシウム結晶（CPPD）を認め た貴重な症例を経験したので報告する。

\section{症例}

79歳, 男性. 既往歴として, 脳梗塞（麻痺な し), 高血圧症, 糖尿病がある。特に外傷等の誘 因なく，2008年10月上旬より右小指の伸展障害 が出現. その2週間後に右環指の伸展障害が出現 し，10月下旬に当科初診。初診時，右環 - 小指 の伸展障害を認め, 右有鈎骨背側付近に $1 \mathrm{~cm}$ 大の 腫瘤を触知した。また，右手関節背屈にて軽度 手関節痛が出現した。 その他の手指や手関節の 運動障害や感覚障害は認めず，また圧痛点も認 めなかった。レントゲン検査では以前に受傷し たものと思われる尺骨茎状突起骨折を認め，ま た軽微な尺骨plus varianceを認めた。 頝椎，肘部 の精査では, それらの部位から生じる神経障害 は考えづらく，また身体所見・採血等の諸検査 でも関節リウマチ（RA）は否定され，11月中旬
に手術を施行．右手背から第2中手骨近位にかけ ての弓状皮切を置き展開すると，第 4 ・5指総指 伸筋腱の皮下断裂を認めた。そのため, 固有示 指伸筋腱を同定し腱移行術を施行した。術前に 遠位橈尺関節（DRUJ）の関節症性変化を認めた ため, Sauve-Kapandji法も施行している. 術中, 伸筋腱皮下断裂部位からDRUJにかけて，黄白色 粒状の滑膜様組織を認め, 病理組織検査にて, 大小不同の石灰化物の沈着をみる滑膜組織であ り，CPPDと同定された。

\section{考察}

CPPDによる手指伸筋腱断裂は比較的まれであ り報告も多いとは言えない。また，膝に代表さ れる大関節と異なり，レントゲン検査にて手根 骨部・手関節部で石灰化を認めることは非常に 難しい。採血等の検査から偽痛風 (pseudogout), CPPD沈着症と診断するのは困難である。今回 我々は，外傷等の誘因のない手指伸筋腱皮下断 裂を認めた場合に，CPPD沈着により惹起される 伸筋腱断裂も考慮する必要があると考えた。 